\title{
Dampak Interaksi Sosial Masyarakat Transmigran Sasak di Manggelewa Dompu NTB
}

\author{
Syarifuddin ${ }^{1}$, Dwi Setiawan Chaniago, Arif Nasrullah, Khalifatul \\ Syuhada \\ Universitas Mataram
}

\begin{abstract}
This study examines the impact of social interactions of the Sasak transmigrants community in Dompu County Manggelewa. The release of transmigrants in this transmigration area certainly has the process of adaptation and assimilation of both communities, both migrants and local communities. The method of research used is to use a qualitative approach. Data collection is done through observation, in-depth interview (Indept interview) and FGD. $F G D$ is used to complement the results of observation and interviews in depth. Data analysis is conducted through three phases of data reduction, classification and draw conclusions based on the overall data. The results of the research of local people and Sasak transmigrants have an equivalent interaction pattern, which tends to be associative. This can be seen from the social relations between Sasak migrant citizens with local people in various social activities that take place. Although between these two groups of people has a different social background that includes language, customs and political opportunities, they remain equal interactions. Assimilation and Acculturas are indicated by the habit of the two groups because it is vulnerable to a long time. The existence of Sasak migrant citizens in Manggelewa for a long time has made the two communities to adapt to each other. As in the event of a resident of Sasak migrant citizen with local people who choose to define new habits. The habit formed is the unification of two or more assimilated cultures.
\end{abstract}

Keywords : Impact, Social Interaction, Transmigrants, Sasak, Manggelewa

\begin{abstract}
Abstrak
Penelitian ini mengkaji tentang dampak interaksi sosial masyarakat transmigran sasak di Manggelewa Kabupaten Dompu. Bertahannya transmigran pada daerah transmigrasi ini tentunya memiliki proses adaptasi dan asimilasi dari kedua masyarakat tersebut, baik pendatang maupun masyarakat lokal. Adapun metode penelitian yang digunakan adalah dengan menggunakan pendekatan kualitatif. Pengumpulan data dilakukan melalui observasi, wawancara mendalam (indept interview) serta FGD. FGD dipergunakan untuk melengkapi hasil observasi dan wawancara mendalam. Analisis data dilakukan melalui tiga tahapan reduksi data, klasifikasi dan penarikan kesimpulan berdasarkan dari keseluruhan data. Hasil penelitian Masyarakat lokal dan masyarakat transmigran sasak memiliki pola interaksi yang setara, sehingga cenderung asosiatif. Hal ini dapat dilihat dari hubungan sosial antara warga transmigran sasak dengan warga lokal dalam berbagai kegiatan sosial yang berlangsung.Walaupun antara kedua kelompok masyarakat ini memiliki perbedaan latar belakang sosial mencakup bahasa, kebiasaan maupun kesempatan politik, mereka tetap menjalin interaksi yang setara. Asimilasi dan akulturas ditunjukkan dengan menyatunya kebiasaan kedua kelompok masyarakat karena rentan waktu yang lama. Keberadaan warga transmigran sasak di Manggelewa dalam jangka waktu lama itulah membuat kedua
\end{abstract}

\footnotetext{
${ }^{1}$ syarifuddinsyarifuddin0@gmail.com
} 
masyarakat saling menyesuaikan diri. Sebagaimana yang berlangsung pada acara pekawinan antara warga transmigran sasak dengan warga lokal yang memilih untuk menentukan kebiasaan baru. Kebiasaan yang terbentuk itu merupakan penyatuan dua atau lebih kebudayaan yang saling berasimilasi.

Kata Kunci : Dampak, Interaksi Sosial, Transmigran, Sasak, Manggelewa

\section{Pendahuluan}

Perpindahan penduduk telah lama dilakukan oleh masyarakat baik dari desa ke kota maupan dari kota ke desa. Perpindahan itu dilakukan akibat adanya kesenjangan kondisi sosial ekonomi yang cukup menonjol antara daerah pedesaan dan perkotaan.Salah satu solusi yang dicanangkan oleh pemerintah dalam mengatasi kesenjangan yang terjadi antara pedesaan dan perkotaan serta mendorong masyarakat untuk mencari alternatif, guna meningkatkan penghasilan yakni dengan melaksanakan program transmigrasi. Program transmigrasi di Indonesia ini memperoleh perhatian pemerintah sejak tahun 1970an melalui Keputusan Presiden Nomor: 1 Tahun 1973.

Transmigrasi merupakan salah satu sub sistem pembangunan yang dicanangkan oleh pemerintah, diarahkan untuk menata persebaran penduduk sehingga dapat mengurangi kepadatan penduduk perkotaan. Program transmigrasi ini umumnya berlangsung pada masyarakat yang memiliki pendapatan yang rendah serta tidak memiliki lahan yang cukup untuk dikelola, sehingga pendapatannya minim. Dengan menjalankan program transmigrasi ini, pemerintah mengurangi masalah kemiskinan dan kepadatan penduduk terutama yang ada di pulau Jawa, Bali dan Lombok. Pemerintah memberikan kesempatan kerja bagi masyarakat untuk memenuhi kebutuhan tenaga kerja dengan mengolah sumber daya di berbagai daerah. Nusa Tenggara Barat merupakan salah satu Propinsi asal dan sekaligus propinsi tujuan transmigrasi. Hal ini dilakukan oleh pemerintah Propinsi Nusa Tenggara Barat bertujuan membuka lapangan pekerjaan baru dan mengurangi pengangguran akibat kepadatan penduduk yang tidak merata.

Transmigrasi di propinsi Nusa Tenggara Barat telah berlangsung sejak tahun 1981/1982. Propinsi Nusa Tenggara Barat terdiri dari dua pulau besar yaitu pulau Lombok dan Pulau Sumbawa, menghadapi permasalahan persebaran penduduk yang tidak merata. Dengan jumlah penduduk sebanyak 4.434.012 jiwa, sebagian besar bermukim di Pulau Lombok yaitu 3.168.692 jiwa, padahal luas wilayah pulau Lombok mencapai 4.738,65 Km2, sedangkan Pulau Sumbawa dengan luas 15.414,50 Km2 hanya berpenduduk 1.331 .520 jiwa (NTB dalam Anggka 2017). 
Beberapa daerah penerima transmigrasi masyarakat Nusa Tenggara Barat (NTB) tersebar di Pulau Sumbawa, Kabupaten Dompu, Kabupaten Bima dan masyarakat sasarannya adalah masyarakat Lombok dan masyarakat Bali. NTB sebagai daerah transmigrasi melaksana kegiatan penyiapan pemukiman, penempatan dan pembinaan di pulau Sumbawa, Dompu dan Bima sebagai daerah transmigrasi lokal (Data DisnaKerTrans NTB, 2016).

Kabupaten Dompu merupakan salah satu kabupaten yang menampung transmigran terbanyak kedua yang ada di NTB. Transmigran ditempatkan di Manggelewa. Manggelewa adalah salah satu kecamatan dari delapan Kecamatan yang ada di Kabupaten Dompu yang menjadi daerah tujuan transmigrasi. Kedatangan transmigrasi tentunya sangat mempengaruhi hubungan sosial yang terjadi, baik antara masyarakat lokal maupun masyarakat pendatang. Berdasarkan data Dinas Transmigrasi NTB, bahwa Kabupaten Dompu telah menampung 2.675 kepala keluarga atau 12.684 Jiwa dari tahun 1980-2010. Para transmigrasi berasal dari Pulau Lombok dan Bali.

Hadirnya para transmigran di tengah-tengah kehidupan masyarakat lokal akan menimbulkan proses sosial melalui interaksi sosial. Interaksi sosial ini akan memunculkan pengetahuan-pengetahuan mengenai proses-prose sosial yang terjadi di masyarakat transmigran. Proses sosial ini dapat dipahami dari segi dinamika yang terjadi pada masyarakat transmigran. Bentuk umum dari proses sosial adalah adanya interaksi sosial. Interaksi sosial merupakan hubungan-hubungan sosial yang dinamis menyangkut hubungan individu dengan individu, individu dengan kelompok maupun antara kelompok dengan kelompok saling berhubungan satu sama lain.

Adapun rumusan masalah penelitian sebagai berikut: Bagaimana dampak interaksi sosial terhadap kehidupan masyarakat pendatang (transmigran) sasak dengan masyarakat lokal di Kecamatan Menggelewa Kabupaten Dompu? Tujuan melakukan penelitian untuk mengetahui dampak interaksi sosial masyarakat pendatang (transmigran) sasak dengan masyarakat lokal di Menggelewa Kabupaten Dompu

\section{Tinjauan Teoritik}

Konsep interaksi sosial merupakan inti dari kajian sosiologi, di mana interaksi sosial dapat dipandang sebagai suatu gejala yang dapat menimbulkan masalah sosial. Interaksi sosial yang berlangsung rutin dalam kehidupan masyarakat dapat membentuk kenyataan atau realitas sosial. Bentuk interaksi sosial secara umum akan mengarah pada bentuk asosiatif (kerjasama) dan disosiatif (pertentangan). Hal ini sebagaimana diungkapkan oleh Gillin dan Gillin bahwa dampak dari interaksi sosial yakni adanya proses yang asosiatif meliputi akomodasi, akulturasi dan asimilasi. Sedangkan proses sosial yang disosiatif meliputi persaingan dan pertentangan (Suyanto, 2004). Dalam masyarakat seringkali terjadi 
kedua proses tersebut. Interaksi sosial akan mengarah pada kerja sama apabila masyarakat memiliki tujuan yang sama melalui proses akulturasi, asimilasi. Masyarakat transmigran sasak dan masyarakat lokal Dompu dalam kehidupan sehari-hari melakukan interaksi sosial.

Dengan kata lain, terjadi pembauran atau akulturasi kebudayaan. Pembauran atau akulturasi sebagaimana pendapat Koentjaraningrat, merupakan proses pencampuran dua kebudayaan atau lebih dan tidak menghilangkan budaya lama. Dalam akulturasi dimaknai sebagai suatu proses sosial yang timbul apabila suatu kelompok manusia dengan suatu kebudayaan tertentu dihadapkan dengan unsur kebudayaan asing sedemikian rupa sehingga unsur-unsur kebudayaan lambat laun diterima dan diolah dalam kebudayaan sendiri tanpa menyebabkan hilangnya kepribadian dari kebudayaan tersebut, (Koentjaraningrat, 2002).

Kenyataan atau realitas sosial yang dibentuk oleh masyarakat tersebut dapat membentuk suatu kebiasaan-kebiasaan baru sehingga menciptakan kerukunan maupun perpecahaan. Secara gagasan interaksi sosial itu terjadi pada individu sebagai bagian dari masyarakat sebagaimana dikembangkan oleh Petter L. Berger dan Thomas Luckmann. Di mana mereka memandang individu-individu yang ada dalam masyarakat dapat menciptakan suatu realitas sosial.

Berger dan Luckman memulai penjelasan realitas sosial dengan memisahkan kualitas yang terdapat di dalam realitas-realitas, yang diakui memiliki keberadaan (being) yang tidak tergantung kepada kehendak kita sendiri. Melainkan dibentuk oleh realitas yang ada dalam kehidupan masyarakat berdasarkan pengetahuan yang dimiliki oleh anggota masyarakat tersebut. Sedangkan pengetahuan didefinisikan sebagai kepastian bahwa realitas-realitas itu nyata atau reel dan memiliki karakteristik yang spesifik. Dalam pandangan Berger dan Luckman terdapat tiga tahap proses terbentuknya hubungan sosial dalam masyarakat. Pandangan Berger dan Luckman mengatakan hubungan sosial masyarakat tercipta dan dipertahankan atau diubah melalui tindakan dan interaksi manusia (Samuel, 2012)

Interaksi sosial dapat menciptakan kesadaran masyarakat melalui tiga tahap yakni objektifasi, eksternalisasi dan internalisasi. Kesadaran sosial itu nyata secara obyektif, namun pada kenyataannya semuanya dibangun dalam definisi subjektif melalui proses interaksi. Hal ini disebut sebagai realitas objektif. Obyektivitas baru bisa terjadi melalui penegasan berulang-ulang yang diberikan oleh orang lain yang memiliki definisi subyektif yang sama. Berdasarkan hal itu masyarakat dapat menciptakan suatu kebudayaan yang baru yang disepati bersama berdasarkan dari hasil interaksi sosial tersebut. Pada tingkat generalitas yang paling tinggi, manusia menciptakan dunia dalam makna simbolik yang universal, yaitu pandangan hidupnya yang menyeluruh, yang memberi legitimasi dan mengatur bentuk-bentuk sosial serta memberi makna pada berbagai bidang kehidupannya. Pendek kata, 
terjadi dialektika antara individu menciptakan masyarakat dan masyarakat menciptakan individu (Brouwer.1984).

\section{Metode Penelitian}

Penelitian ini menggunakan pendekatan kualitatif deskriptif, di mana hal ini dimaksudkan agar dapat memahami dampak interaksi sosial masyarakat transmigran secara mendalam. Sehingga realitas sosial dapat diungkapkan secara alami berdasarkan sudut pandang subjek penelitian. Pada tahap awal penelitian dilakukan pengumpulan data terkait dampak interaksi sosial masyarakat pendatang (transmigaran) dengan penduduk lokal. Kemudian selanjutnya mengumpulkan data terkait dengan bentuk asimilasi dan akulturasi budaya yang terjadi pada masyarakat transmigran sasak di Manggelewa Dompu.

Adapun lokasi penelitian yang dipilih adalah di Manggelewa Kabupaten Dompu yang banyak menampung transmigran dari Suku Sasak. Dasar pemilihan lokasi ini bahwa Kabupaten Dompu merupakan salah satu kabupaten yang ada di Pulau Sumbawa yang menerima atau daerah tujuan transmigran yang di canangkan oleh pemerintah Nusa Tenggara Barat. Di sisi lain kebudayaan dari kedua masyarakat yaitu masyarakat pendatang (transmigran) Sasak dengan masyarakat lokal Dompu suku Bima (Dou Mbojo) memiliki perbedaan yang cukup menonjol sehingga apabila terjadi asimililasi dan akulturasi budaya akan muncul suatu hal yang berbeda.

Subjek penelitian merupakan masyarakat transmigran sasak (pendatang) dan masyarakat lokal Dompu suku Bima (Dou Mbojo). Subjek penelitian dipilih dengan menggunakan cara purposive, yakni subjek dipilih secara sengaja atau berdasarkan pertimbangan-pertimbangan berdasarkan tujuan penelitian. Sumber data penelitian berasal dari hasil wawancara mendalam, observasi dan fokus group discussion, sedangkan data sekunder berasal dari berbagai literatur baik dari buku, koran, maupun dari penelitian yang pernah dilakukan sebelumnya terkait dengan transmigrasi di Nusa Tenggara Barat sebagai pembanding dalam penelitian. Analisis data dengan melakukan reduksi data yang tersedia, yang dikumpulkan melalui berbagai tahapan observasi, wawancara mendalam maupun fokus group discussion dan ditulis dalam bentuk fieldnote. Selanjutnya dipilah dengan melihat kesamaan data dan selanjutnya dikelompokkan untuk mencari data yang relevan dengan konteks penelitian

\section{Hasil Penelitian}

Warga transmigran yang ada di Manggelewa Dompu mayoritas berasal dari suku sasak Pulau Lombok. Sehingga sebagai warga pendatang, warga di Manggelewa masih kental dengan kebiasaan atau budaya yang berasal dari daerah asal transmigran yakni Lombok. Kebiasaan-kebiasaan yang di praktekkan di 
Manggelewa tersebut memiliki perbedaan dengan kebiasaan yang dimiliki oleh masyarakat lokal. Adapun perbedaan kebiasaan yang menonjok adalah bahasa yang dipergunakan oleh warga lokal dan warga transmigran. Sehingga dari perbedaan bahasa ini akan berimplikasi pada perbedaan yang lain, sebut saja ritual yang dilakukan pada upacara perkawinan (merariq), pelaksanaan Maulid Nabi maupun kegiatan yang menunjukkan solidaritas yang unik dari kedua kelompok masyarakat tersebut. Walaupun perbedaan yang dimiliki tersebut tidak terlalu mencolok, akan tetapi berimplikasi pada berlangsungnya interaksi sosial antara kedua masyarakat tersebut, (Hasil Observasi 25 Agustus 2018). Dari segi kewilayahan, Manggelewa awalnya merupakan hasil pemekaran dari Kecamatan Kempo pada tanggal 29 Desember 2002. Nama Manggelewa itu di abadikan melalui proses analisa sejarah yang mendalam oleh para tokoh pencetus terbentuknya Kecamatan Definitif Manggelewa.

\section{Adaptasi Masyarakat Transmigran dengan Masyarakat Lokal Dompu}

Pada dasarnya manusia merupakan makhluk sosial, di mana mereka tidak sanggup menjalani kehidupan secara individu. Manusia membutuhkan manusia lain sehingga membentuk suatu kelompok selanjutnya menjadi suatu komunitas dan berkembang menjadi masyarakat. Begitupula yang terjadi pada masyarakat transmigran sasak di Manggelewa Dompu. Walaupun masyarakat transmigran sasak telah memiliki modal untuk menaklukan alam secara fisik dan psikis akan tetapi tetap membutuhkan manusia lain dalam kehidupan melalui interaksi sosial dengan masyarakat lokal.

Pada mulanya antara masyarakat sesama transmigran sasak tidak saling mengenal karena berasal dari berbagai daerah yang berbeda di Pulau Lombok dan jarak antar rumah berjauhan. Namun hal itu tidak menjadi kendala bagi warga sesama transmigran ataupun dengan masyarakat lokal Dompu saling mengenal antara satu dengan yang lainya. Manusia memiliki dorongan dari dalam untuk mengenal satu sama lain melalui berbagai kegiatan seperti jual beli, pendidikan, pengajian ataupun kelompok tani serta kegiatan menanam dan panen saling membutuhkan satu sama lain. Hal ini diungkapkan oleh (hasil indept- interview dengan pak Wahid 55 tahun).

Keberadaan suku sasak warga transmigran di Manggelewa Dompu memberikan warna tersendiri bagi kehidupan sosial masyarakat lokal Dompu. Umumnya masyarakat lokal Dompu berada disekitar Manggelewa. Sebagaimana yang terjadi pada acara perkawinan campuran. Pada mulanya masyarakat lokal melakukan acara resepsi dikelola oleh pihak perempuan, pihak laki-laki hanya menyerahkan sejumlah dana kepada pihak perempuan. Sedangkan masyarakat sasak mengadakan acara perkawinan pada pihak laki-laki dan juga menyerahkan mahar kepada perempuan akan tetapi acara perkawinan tetap dilakukan oleh pihak laki- 
laki dilanjutkan untuk mengantar pada keluarga pihak perempuan pada waktu yang disepakati.

Akan tetapi realitasnya, kedua masyarakat ini telah membangun kebiasaan baru ketika berada di Manggelewa Dompu. Hal ini dapat dilihat dari perkawinan campuran yang terjadi antara warga lokal Dompu dengan warga transmigran lebih banyak mengadopsi budaya asli sasak. Walaupun mempelai pria ataupun wanita adalah warga Dompu. Akan tetapi upacara dilakukan sesuai dengan kebiasaan sasak yang telah dimodifikasi sesuai kesepakatan dari kedua belah pihak. Pertama mulai dari mahar yang disediakan oleh keluarga mempelai pria dengan menyediakan mahar sampai pada upacara perkawinannya tidak lagi menggunakan kebiasaan masyarakat lokal. hal ini dilakukan karena masyarakat lokal dikenal lebih mahal dalam menentukan biaya perkawinan termasuk mahar yang akan disediakan lebih mahal (Wawancara Haji Olan, 25 Agustus 2018).

Ketika perkawinan campuran terjadi antara suku sasak dan suku bima yang ada di Dompu, maka masyarakat cenderung memilih kebiasaan masyarak sasak yang disepakati bersama oleh keluarga yang berhajat. Dengan cara resepsi dilakukan dan dikelola oleh pihak mempelai pria dan yang banyak menghadiri adalah keluarga mempelai pria, selanjutnya akan diadakan nyongkolan (mengantar mempelai perempuan dengan iring-iringan keluarga pria dengan musik). Kebiasaan ini dibangun untuk mengurai perbedaan kebiasaan sekaligus menekan biaya perkawinan bagi masyarakat lokal Dompu dengan warga transmigran sasak.

Di sisi lain lain suku sasak dan suku Bima keduanya memiliki bahasa yang berbeda. Perbedaan itu cukup jauh sehingga kedua masyarakat cenderung mempertahankan bahasa masing-masing. Warga transmigran memiliki kebiasaan menggunakan bahasa sasak sedangkan warga lokal menggunakan bahasa Bima dan memiliki arti dan makna yang berbeda. Sehingga untuk menjembatani perbedaan itu masyarakat seringkali menggunakan bahasa Indonesia dalam berkomunikasi setiap hari. Bahasa Indonesia yang dipergunakan juga jauh dari kata baku, warga lebih banyak mencampurnya dengan bahasa lokal Dompu, sehingga warga transmigran mengalami kesulitan untuk memahami perbagai hal yang disampaikan oleh penduduk lokal Dompu (hasil FGD, 28 Agustus 2018).

\section{Dampak Interaksi sosial Masyarakat Transmigran Sasak di Manggelewa}

Kebiasaan yang terbentuk di masyarakat merupakan hasil dari interaksi sosial masyarakatnya. Kebiasan yang dimiliki oleh masyarakat juga mengalami perubahan seiring dengan perkembangan masyarakat dan juga pengaruh dari masyarakat pendatang. Warga pendatang atau transmigran seringkali membawa kebudayaan yang berbeda dengan masyarakat lokal sehingga berdampak baik positif maupun negatif. Interaksi sosial masyarakat transmigran sasak dan masyarakat lokal di Manggelewa mengarah kepada hubungan sosial yang asosiatif. 
Hal ini sebagai mana hasil wawancara dengan subjek penelitian terlihat dari kegiatan-kegiatan sosial dari kedua kelompok masyarakat yang melakukan kerjasama, tolong menolong, gotong royong pada setiap kegiatan.

Sedangkan dampak negatif dari interaksi sosial yang berlangsung antara kedua kelompok masyarakat ini tidak terlalu nampak. Menurut subjek penelitian, warga transmigran sasak memilih untuk mengalah ketika terjadi pertentang antara kedua kelompok. Masyarakat transmigran sasak menyadari keberadaannya di Manggelewa sebagai pendatang sehingga perselisihan antara kedua kelompok dapat diselesaikan dengan musyawarah dan mufakat antara pihak-pihak yang terlibat.

Berdasarkan hasil wawancara dengan perangkat desa maupun masyarakat transmigran dan masyarakat lokal bahwa transmigrasi ini memberikan sumbangsi positif bagi pembangunan dan kemajuan daerah dalam meningkatkan taraf hidup masyarakat. Secara umum telah memberikan kontribusi terhadap pembangunan daerah dan telah membawa perkembangan yang cukup berarti bagi pengembangan wilayah dan peningkatan perekonomian diantaranya; Mendukung terwujudnya swasembada pangan melalui penambahan luas areal pertanian dan perkebunan. Dapat menciptakan lapangan kerja disektor pertanian sehingga dapat membantu mengatasi masalah pengangguran dan kemiskinan. Tumbuhnya pusat-pusat produksi baru yang berbasis pertanian, yaitu pengembangan jambu mente di Manggelewa. Serta pemerataan pelayanan kesehatan dan keluarga berencana melalui pembangunan PUSTU dilengkapi dengan sarana kesehatan. Pemerataan pelayanan pendidikan tingkat SD/SMP. Membangun aksesibilitas dengan membuka daerah-daerah yang terisolir, sehingga dapat memperlancar arus transportasi dan pemasaran serta mengoptimalkan pemanfaatan sumber daya alam (SDA), dengan membangun sarana dan prasarana

\section{Kesimpulan}

Bentuk insakralitas pernikahan dalam pemilihan jodoh pada keluarga kontemporer dapat dilihat dari indikator eligibilitas yang dilihat dalam dua dimensi utama yakni kemampuan (kapabilitas) calon pasangan dengan mempertimbangkan aspek keagamaan, dan aspek ekonomi. sedangkan dimensi kedua adalah boleh atau tidak pasangan dipilih dan pernikahan dilangsungkan. Bentuk insakralitas terjadi berdasarkan eligibilitas kemampuan terjadi dalam bentuk tidak optimalnya pertimbangan-pertimbangan keagamaan dan ekonomi dalam pemilihan jodoh dan pernikahan. Tidak eleigiblenya yang berujung pada insakralitas pemilihan jodoh dan pernikahan tersebut akibat kapabilitas keagamaan dan ekonomi lebih banyak tersimplikasi dengan anggapan jodoh dan rezeki sebagai takdir yang telah ditetapkan sehingga disikapi secara fatalis. Jika dilihat dari boleh atau tidaknya 
suatu pasangan dipilih dan pernikahan dilangsungkan melahirkan bentuk insakralitas dimana aspek sosio-kultural, dan aspek hukum yang belum dipertimbangkan secara optimal.

\section{Daftar Pustaka}

Afrizal. 2014. Metode Penelitian Kualitatif. Jakarta: Rajawali Pers.

Hanoman, Samuel. 2012. Peter Berger Suatu Pengantar Ringkas. Depok: Penerbit Kepik.

Haren, H.J. 1997. Transmigrasi di Indonesia. Jakarta: Gramedia

Horton, Paul B, dan Chester L. Hunt. 1992. Sosiologi, Jilid 1, Edisi Keenam, Jakarta: Erlangga.

Http://pelayanan-publik.kampung-media.com/2014/02/24/manggelewa-dalamtatanan-perencanaan-pembangunan-1189

Huzaimah, Siti. 2015. Interaksi Sosial Transmigran suku Jawa dengan Penduduk Pribumi Lampung di Kampung Bumi Putra, Lampung. Skripsi. www.digilib.uin-suka.ac.id. Di akses 03 Februari.

Ittihad, I. 2016. Peran Masyarakat Pendatang Dalam Memajukan Desa Belanting Kecamatan Sambelia. PALAPA: Jurnal Studi Keislaman dan Pendidikan, 3 (1),108128.http://ejournal.kopertais4.or.id/sasambo/indeks.php/palapa/articl e/view/2189

M.A.W. Brouwer.1984. Psikologi Fenomenologis. Jakar32vgfxta. PT. Gramedia.

Narwoko, J. Dwi, dan Suyanto Bagong. 2004. Sosiologi teks Pengantar dan Terapan. Jakarta: Kencana.

Soekanto, Soerjono. 2001. Sosiologi Suatu Pengantar, Edisi Keempat, Cetakan Ketigapuluh satu, Jakarta: PT Raja Grafindo Persada.

Warsito, Rukmadi \& Kustadi Sujarwadi. Dkk. 1984. Transmigrasi (dari Daerah Asal Sampai Benturan Budaya di Tempat Pemukiman). Jakarta: Rajawali. 